\title{
Spinal Epidural Abscess Associated with Epidural Anesthesia: Gadolinium-Enhanced Magnetic Resonance Imaging and Its Usefulness in Diagnosis and Treatment
}

\author{
Takakazu Higuchi, Atsuko Imagawa, Makoto Murahashi, Hajime Hara and Yoshihiro Wakayama \\ A case of spinal epidural abscess following epidural anesthesia is described. Gadolinium- \\ enhanced magnetic resonance images were essential in diagnosis of the abscess without frank pus \\ formation, in defining the extension of the infection, and in assessing the therapeutic effect. The \\ patient was successfully treated non-operatively before neurological symptoms developed and full \\ recovery was achieved.
}

(Internal Medicine 35: 902-904, 1996)

Key words: phlegmonous stage, antibiotics

\section{Introduction}

Spinal epidural abscess (SEA) is a rare condition and comprises between 0.2 and 1.6 cases per 10,000 hospital admissions (1-3). Most of the cases of SEA are the consequence of trauma, spinal procedure, extension of adjacent infection, or hematogenous seeding of a distant focus $(1,2,4-7)$. However, despite the widespread practice of epidural anesthesia and, in addition, frequently contaminated epidural catheters (8), SEA following epidural anesthesia is extremely rare (9-11). Questionnaire studies directed to obstetricians revealed only one SEA among 505,000 epidural anesthesia in the United Kingdom between 1982 and 1986 (12) and none among 288,351 in France between 1988 and 1993 (13). In spite of its rarity, SEA is a neurosurgical emergency, often taking a disastrous sequel with rapid and irreversible neurological deterioration due to the impairment of the circulation of the spinal cord $(1,2,5,7)$. As its prognosis is related to the duration of the infectious process, early diagnosis is crucial $(2,5)$.

We present a case of SEA without a frank pus formation following epidural anesthesia. Gadolinium (Gd)-enhanced magnetic resonance (MR) images were diagnostic. The diagnosis was prompt enough to successfully treat non-operatively before the development of neurological symptoms and to allow a complete recovery.

\section{Case Report}

An otherwise healthy 35-year-old male had high ligation of left testicular veins for varicocele under epidural anesthesia. Following identification of the epidural space using a loss of resistance technique with sterile normal saline, an epidural catheter was inserted $5 \mathrm{~cm}$ beyond the top of Tuohy needle at L3-4 and $10 \mathrm{ml}$ of $2 \%$ mepivacain hydrochloride was injected. All the procedures were under aseptic technique and prophylaxic intravenous piperacillin had been started. After the operation, continuous injection of $40 \mathrm{ml}$ of $1 \%$ mepivacain hydrochloride with two additional shots of morphine hydrochloride solution ( $5 \mathrm{mg}$ and $2 \mathrm{mg}$, respectively, in $10 \mathrm{ml}$ of normal saline) were given through the epidural catheter. The catheter was removed 72 hours after its insertion.

He complained of backache near the catheter insertion site soon after the operation and his body temperature elevated to $38.4^{\circ} \mathrm{C}$ on the first post-operative day. The site of catheter insertion appeared to be devoid of infection, however, a tenderness was noted there. Piperacillin was continued for three days, then his body temperature returned to normal and he had incomplete convalescence of the backache and piperacillin was replaced with oral tosufloxacin. He was discharged on the 5th post-operative day.

After discharge, however, low grade fever developed again in spite of continuous administration of tosufloxacin; on the 8th post-operative day, his body temperature elevated to over $38^{\circ} \mathrm{C}$ and his backache worsened. He was admitted again. Physical

From the Department of Internal Medicine, Showa University Fujigaoka Hospital, Yokohama

Received for publication April 11, 1996; Accepted for publication August 8, 1996

Reprint requests should be addressed to Dr. Takakazu Higuchi, the Department of Internal Medicine, Showa University Fujigaoka Hospital, 1-30 Fujigaoka, Aoba-ku, Yokohama 227 
and neurological examinations were unremarkable except for a tenderness at the site of catheter insertion.

The white blood cell count was $12,600 / \mu$ with $65 \%$ neutrophils. C-reactive protein was $16.4 \mathrm{mg} / \mathrm{dl}$. An abdominal computed tomography (CT) failed to detect any abnormalities. Lumbar puncture at L2-3 interspace revealed a cerebrospinal fluid (CSF) pressure of $190 \mathrm{mmH}_{2} \mathrm{O}$, glucose $56 \mathrm{mg} / \mathrm{dl}$, total protein $115 \mathrm{mg} / \mathrm{dl}$, and microscopy revealed mild pleocytosis with a cell count of $52 / \mu$ l (neutrophils $42 / \mu \mathrm{l}$ ). These findings were considered to be typical of parameningeal infection. Neither blood nor CSF yielded any bacteria. T1-weighted MR images (Fig. 1A Left) showed mild narrowing of the spinal canal at L4-5 level caused by swelling of the posterior soft
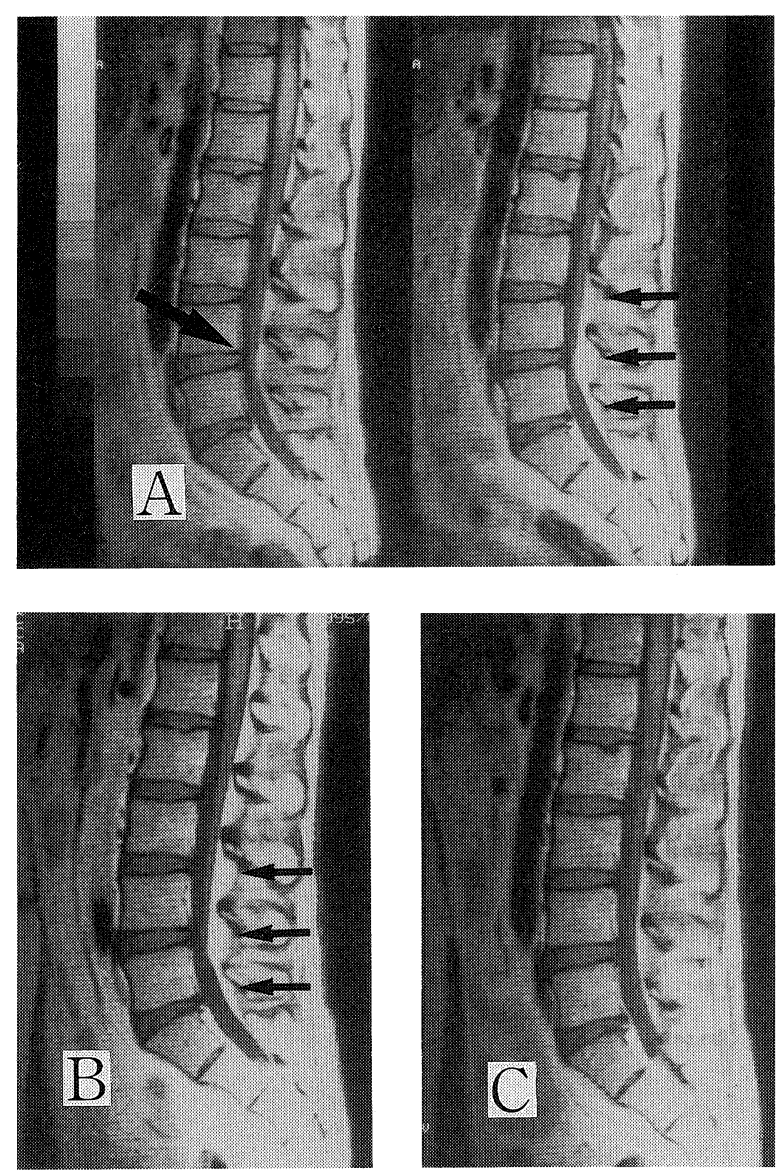

Figure 1. (A) Sagittal MR images at diagnosis of spinal epidural abscess. (Left) T1-weighted image (repetition time: 500; echo time: 25 ) without Gd-enhancement shows mild narrowing of spinal canal at L4-5 level (arrow) caused by swelling of the posterior soft tissue. (Right) Gd-enhanced MR image depicts homogeneous enhancement (arrows) of the posterior epidural space between L3 and S1, thickest at L4-5 level. (B) Gd-enhanced MR image taken 12 days later shows alleviation of the narrowing of the spinal canal, however, homogeneous enhancement of the posterior epidural space still persists (arrows). (C) Follow-up MR image after discontinuation of the antibiotics no longer shows Gdenhancement of the posterior epidural space. tissue. The signal intensity of the posterior margin of the fat was decreased, causing the area isointense to the muscles to widen. After Gd-enhancement (Fig. 1A Right), the posterior epidural space was homogeneously enhanced between L3 and S1, thickest at L4-5 level. These findings were interpreted as an epidural abscess in phlegmonous stage.

Intravenous cefpirome $6 \mathrm{~g} /$ day and ampicillin $8 \mathrm{~g} /$ day were started and his fever subsided in three days. On the follow-up MR images taken 12 days later (Fig. 1B), the narrowing of the spinal canal was alleviated, however, homogeneous Gd-enhancement of the posterior epidural space persisted. The antibiotics were given for 27 days. Repeated MR images taken 10 days after discontinuation of the antibiotics (Fig. 1C) no longer revealed $\mathrm{Gd}$-enhancement of the epidural space. The recovery was complete.

\section{Discussion}

SEA is a very rare condition and those complicating epidural anesthesia are even rarer $(1,2,12,14)$, however, it is a neurosurgical emergency and prompt diagnosis is crucial to reduce the mortality and not to leave neurological impairment $(2,5)$. Myelography has been the procedure of choice in diagnosis of SEA $(1,2,4,5)$. Nowadays it appears that MR imaging is superior to myelography $(6,7,14-17)$ because of the following reasons. The former can demarcate anatomical localization of SEA which, in average, extends four to five vertebral segments (1), discriminate active viable inflammation with Gd-enhancement $(16,18)$, and avoid the potential risk of disseminating the infection by penetrating the abscess by needle during the latter $(1,7,14)$. Gd-enhanced MR imaging is considered to be especially useful in diagnosis of SEA in phlegmonous stage which pathologically corresponds to granulomatous thickened tissues with embedded microabscess without a collection of liquid pus (15). In the present case, it is likely that prophylactic administration of antibiotic might prevent apparent pus formation and SEA developed only to phlegmonous stage when diagnosis was made. We, therefore, suggest that patients who have fever and back pain after epidural anesthesia should be examined by Gd-enhanced MR images. Our case also confirmed that serial Gd-enhanced MR images were useful in evaluating the therapeutic effects (3) and we could safely discontinue the antibiotics.

While the treatment of choice for SEA is decompression laminectomy and drainage of the abscess with appropriate use of antibiotics $(1,2,5,6,19)$, sporadic cases successfully treated without surgery have been documented, most of them being diagnosed early enough $(2,6,20-22)$. The present case is another example that could be successfully treated conservatively. We were unable to detect a collection of liquid pus in this case and it is doubtful whether laminectomy with drainage was indicated. This case may exemplify the contention that SEA can be managed conservatively if diagnosed before a frank pus formation and neurological deterioration occur.

The CSF finding of the present case was that of typical parameningeal infection, however, complicating meningitis is 


\section{HiguCHI et al}

often experienced $(1,7)$. Therefore, while Gd-enhanced MR images should precede lumbar puncture for suspected cases of SEA and lumbar puncture is not indispensable in most of the instances, CSF penetration should be taken into consideration when selecting antibiotics as well as causative organisms $(1,2$, 4-8, 23).

\section{References}

1) Baker AS, Ojemann RG, Swartz MN, Richardson EP Jr. Spinal epidural abscess. N Engl J Med 293: 463, 1975.

2) Danner RL, Hartman BJ. Update of spinal epidural abscess: 35 cases and review of the literature. Rev Infect Dis 9: 265, 1987.

3) Nussbaum ES, Rigamonti D, Standiford H, Numaguchi $Y$, Wolf AL, Robinson WL. Spinal epidural abscess: a report of 40 cases and review. Surg Neurol 38: 225, 1992.

4) Kaufman DM, Kaplan JG, Litman N. Infectious agents in spinal epidural abscesses. Neurology 30: 844, 1980.

5) Verner EF, Musher DM. Spinal epidural abscess. Med Clin North Am 69: 375, 1985

6) Ericsson M, Algers G, Schliamser SE. Spinal epidural abscesses in adults: review and report of iatrogenic cases. Scand J Infect Dis 22: 249, 1990.

7) Hlavin ML, Kaminski HJ, Ross JS, Ganz E. Spinal epidural abscess: a tenyear perspective. Neurosurgery 27: 177, 1990.

8) Hunt JR, Rigor BM, Collins JR. The potential for contamination of continuous epidural catheteres. Anesth Analg 56: 222, 1977.

9) Saady A. Epidural abscess complicating thoracic epidural analgesia. Anesthesiology 44: 244, 1976.

10) North JB, Brophy BP. Epidural abscess: a hazard of spinal epidural anaesthesia. Aust N Z J Surg 49: 484, 1979.

11) Ready LB, Helfer D. Bacterial meningitis in parturients after epidural anesthesia. Anesthesiology 71: 988, 1989.

12) Scott DB, Hibbard BM. Serious non-fatal complications associated with extradural block in obstetric practice. Br J Anaesth 64: 537, 1990.

13) Palot M, Visseaux H, Botmans C, Pire JC. Epidémiologie des complications de l'analgésie péridurale obstétricale. Cah Anesthésiol 42: 229, 1994 (in French with English abstract).

14) Angtuaco EJC, McConnell JR, Chadduck WM, Flanigan S. MR imaging of spinal epidural sepsis. Am J Roentgenol 149: 1249, 1987.

15) Sandhu FS, Dillon WP. Spinal epidural abscess: evaluation with contrastenhanced MR imaging. Am J Neuroradiol 12: 1087, 1991.

16) Post MJD, Quencer RM, Montalvo BM, Katz BH, Eismont FJ, Green BA. Spinal infection: evaluation with MR imaging and intraoperative US. Radiology 169: 765, 1988.

17) Erntell M, Holtås S, Norlin K, Dahlquist E, Nilsson-Ehle I. Magnetic resonance imaging in the diagnosis of spinal epidural abscess. Scand J Infect Dis 20: 323, 1988.

18) Post MJD, Sze G, Quencer RM, Eismont FJ, Green BA, Gahbauer H. Gadolinium-enhanced MR in spinal infection. J Comput Assist Tomogr 14: 721, 1990.

19) Sowter MC, Burgess NA, Woodsford PV, Lewis MH. Delayed presentation of an extradural abscess complicating thoracic extradural analgesia. Br J Anaesth 68: 103, 1992.

20) Leys D, Lesoin F, Viaud C, et al. Decreased morbidity from acute bacterial spinal epidural abscesses using computed tomography and nonsurgical treatment in selected patients. Ann Neurol 17: 350, 1985.

21) Mampalam TJ, Rosegay H, Andrews BT, Rosenblum ML, Pitts LH. Nonoperative treatment of spinal epidural infections. J Neurosurg 71: 208, 1989.

22) Reynolds PC, Hahn MB. Early diagnosis of a spinal epidural abscess. Reg Anesth 16: 57, 1991.

23) Ngan Kee WD, Jones MR, Thomas P, Worth RJ. Extradural abscess complicating extradural anaesthesia for caesarean section. Br J Anaesth 69: $647,1992$. 